Ольга Черних, Національний університет оборони України імені Івана Черняхівського ORCID ID 0000-0001-9865-5598

Юрій Черних, кандидат технічних наук, доцент, Військовий інститут Київського національного університету імені Тараса Шевченка

\title{
АНАЛІЗ ІНСТИТУЦІЙНИХ ЗМІН У СИСТЕМІ ПІДГОТОВКИ ОФІЦЕРСЬКИХ КАДРІВ
}

В статті обтрунтовано актуальність дослідження інституиійних змін у системі підготовки військових фахівців з вищою освітою. Необхідність конструктивних змін у системі підготовки офіцерських кадрів, приведення організації та змісту їх навчання до вимог сьогодення вимагає розширення категорійного апарату дослідження иих явищ на основі застосування методологічного інструментарію сучасного інституціоналізму. При цььому, проведення аналізу інституиійних змін, щзо відбулися протягом останніх років у системі підготовки офіцерських кадрів, вимагає системного підходу. Доведено, щуо аналіз трансформації інститутів передбачає вивчення феномену залежності від їхнього попереднього розвитку. 3 врахуванням теоретичних положень інституціоналізму проаналізовано основні зміни, щз відбулися протягом останніх років у системі підготовки офічерських кадрів певних рівнів військового управління (тактичного, оперативного та стратегічного). Ставши на шлях інтегрування в європейську та євроатлантичну спільноту, поставлено амбітні завдання, в тому числі - підняти рівень підготовки офіџерських кадрів до європейських стандартів. Останнім часом Міністерством оборони Украӥни зроблено багато послідовних кроків у иьому напрямку, інституційні зміни у системі підготовки офіцерів, щуо розглянуто, один із них.

Ключові слова: система підготовки; офіцерські кадри; інституційні зміни; лідерські курси.

Постановка проблеми. Зміни воєнно-політичної обстановки у світі, досвід проведення антитерористичної операції та операції Об'єднаних сил вимагають обгрунтування нових підходів до проблем забезпечення національної безпеки, визначення ролі й місця пї Збройних Сил (далі - ЗС) у структурі воєнної організації держави, забезпечення їх бойової та мобілізаційної готовності для захисту національних інтересів, територіальної цілісності та суверенітету України.

Основним напрямом для розв’язання зазначених проблем має стати подальше реформування 3C, їх переоснащення i забезпечення сучасним озброєнням та бойовою технікою, а найголовніше - компетентним особовим складом. В умовах реформування i вдосконалення засад підготовки та застосування військ (сил) на основі принципів і стандартів Організації Північноатлантичного договору (НАТО) одним iз головних завдань $\epsilon$ формування нового офіцерського корпусу, який би складався 3 найбільш 
професійно підготовлених військовослужбовців 3 високими моральноетичними, професійно-важливими та індивідуально-психічними якостями. Реформування і подальший розвиток ЗС України стимулює вдосконалення системи підготовки офіцерських кадрів щодо досягнення іï якості згідно зі стандартами НАТО. Це завдання потребує аналізу змін інституційних підходів до функціонування системи військової освіти та зокрема системи підготовки офіцерських кадрів.

Актуальність дослідження інституційних змін у системі підготовки військових фахівців 3 вищою освітою на теперішній час зумовлена такими чинниками:

- прийняттям упродовж останніх років низки нормативно-правових актів 3 безпекової, оборонної та освітньої політики держави, подальшого розвитку ЗС України [1-6];

- реалізацією курсу на поглиблення партнерства з НАТО в питаннях підготовки офіцерських кадрів, проведення миротворчих, антитерористичних операцій, тренінгів, навчань, ведення збройної боротьби тощо.

У Концепції розвитку сектору безпеки і оборони України [3], одним із шляхів досягнення необхідних оперативних та інших спроможностей складових сектору безпеки i оборони визначено підвищення рівня індивідуальної фахової підготовки особового складу органів державного та військового управління, його відповідальності за прийняття рішень, а також інтенсифікація та професіоналізація такої підготовки.

Аналіз досліджень і публікацій. Проблеми трансформаційних процесів в освіті знайшли грунтовне висвітлення в наукових публікаціях і монографіях вітчизняних і зарубіжних вчених - В. Андрущенка, С. Архангельського, I. Беха, Б. Гершунського, В. Давидова, В. Козакова, В. Кременя, Н. Ничкало, та ін. (проблемні питання філософії освіти, організація та методика навчання та виховання у вищій школі, психологічні аспекти розвитку особистості), В. Лугового, С. Ніколаєнка (управління інноваційною освітою), І. Богданової, Е. Короткова, В. Сластеніна, I. Харламова (технології освітнього процесу), I. Зязюна, С. Подмазіна, В. Серікова (гуманістична освітня парадигма, особистісно орієнтоване навчання), В. Ледньова (зміст освіти), А. Підаєва, В. Передерія (Болонський процес, реформування системи освіти в Свропі та Україні) тощо.

Проблеми підготовки офіцерських кадрів у системі військової освіти України висвітлені в наукових працях В. Артемова, А. Вітченка, О. Діденка, А. Зельницького, Д. Іщенка, М. Нещадима, Б. Олексієнка, Ю. Приходька, В. Стасюка, О. Торічного, В. Ягупова та ін. Зокрема, системному дослідженню військової освіти присвячені наукові праці М. Нещадима $[7 ; 8]$, теоретичні основи трансформації систем, актуальні проблеми сучасного етапу розвитку військової освіти висвітлені в наукових публікаціях Ю. Приходька $[9,10]$.

Аналіз публікацій показує багатоаспектність досліджень процесу трансформації системи підготовки фахівців з вищою освітою, висвітлення його в численних наукових працях філософів, педагогів, психологів, практиків, що тісно пов'язані 3 проблемами, порушеними в статті. Разом 3 тим, у 
проаналізованих дослідженнях і публікаціях інституційні зміни, що відбулися протягом останніх років у системі підготовки офіцерських кадрів для 3С України, не розглядалися.

Мета статті. Проведення аналізу інституційних змін, що відбулися протягом останніх років у системі підготовки офіцерських кадрів, та врахування досвіду реформування національної системи військової освіти для вдосконалення підготовки військових фахівців.

Виклад основного матеріалу. Необхідність конструктивних змін у системі підготовки військових фахівців, приведення організації та змісту їх навчання до вимог сьогодення вимагає розширення категорійного апарату дослідження цих явищ на основі застосування методологічного інструментарію сучасного інституціоналізму.

Видатний американський вчений Дуглас Норт визначив, що інститути - це «правила гри» в суспільстві, або, висловлюючись більш формально, створені людиною обмежувальні рамки, які організовують взаємовідносини між людьми. Отже, вони задають структуру спонукальних мотивів людської взаємодії - будь то в політиці, соціальної сфері або освіті. Інституційні зміни визначають то, як суспільство розвивається в часі, й таким чином $є$ ключем до розуміння історичних змін [11].

Українським економічним енциклопедичним словником [12] інституційні зміни визначаються як безперервний процес кількісно-якісних змін і перетворень різних соціальних і економічних інститутів.

Інституційний підхід $є$ однією з форм організації мультидисциплінарних досліджень в історичній науці, спрямованих на вирішення науково-дослідних завдань в рамках іiї предметного поля за допомогою методів інших наукових дисциплін. Інституційний підхід являє собою систему пізнавальних принципів, що орієнтують вчених на інтерпретацію історичної дійсності в руслі інституційних теорій, розроблених в різних соціально-гуманітарних галузях знань. У якості «інституту» або об'єкта дослідження можуть виступати: організації; правила і норми; моделі поведінки і соціальні практики; когнітивні образи та подання [13].

У сфері освіти інституційний підхід застосовується при аналізі норм діяльності та правил поведінки працівників освітніх закладів, а також принципів взаємодії з іншими громадськими інститутами. Надання освіти як системи інституційних відносин і функціональних взаємозв'язків 3 іншими елементами громадських організацій дозволяе уточнити його роль в умовах трансформації суспільства. Трансформації припускають зміни вже існуючих інститутів, перетворення окремих формальних i неформальних норм, стереотипів поведінки та діяльності. До масштабних трансформацій системи освіти відноситься модернізація, яка супроводжується змінами ii структури, норм функціонування, типів, видів і рівнів освіти та ін. Локальними інституційними трансформаціями $є$ освітні інновації. Вони спрямовані на зміну існуючих освітніх інституцій: системи освітніх закладів, змісту освіти, технологій навчання, умов діяльності суб'єктів освіти, зміни їх взаємовідносин тощо [13]. 
Аналіз трансформації інститутів передбачає вивчення феномену залежності від їхнього попереднього розвитку (path dependency). Розкриття спадкоємності в еволюції інституційної структури із застосуванням методу path dependency було запропоноване американськими вченими П. Девізом i Б. Артуром. Згідно з концепцією Д. Норта, саме інституціональна методологія на основі дослідження наслідків залежності інституційної зміни від іiі шляху уможливлює виявлення закономірностей у процесі історичного розвитку, а також $\epsilon$ підгрунтям для прогнозування майбутніх змін. Учений, зокрема, зазначав: «Ми не можемо зрозуміти теперішніх варіантів вибору, якщо не простежимо поступового розвитку інституцій [11].

Зміна освітньої парадигми являє собою перетворення теоретикометодологічних підстав, пріоритетів, що обумовлюють зміну змісту, форм, методів, засобів освіти і навчання, комунікативних норм педагогічної взаємодії. Прикладами результатів даного виду трансформації можна вважати застосування в практиці освіти наступних концепцій: гуманітаризації, безперервної освіти, інформатизації, ключових компетенцій, якості освіти, а також комплексні імпортовані зміни, зокрема зумовлені інтеграцією у світовий освітній простір (приєднання до Болонської конвенції). Перетворення даного типу пов'язані з впровадженням інституту-зразка, успішно функціонуючого в інших країнах.

3 врахуванням теоретичних положень, що викладені вище, розглянемо основні інституційні зміни, що відбулися протягом останніх років у системі підготовки офіцерських кадрів.

До прийняття Верховною Радою України нової редакції Закону України «Про вищу освіту» [6] підготовка офіцерів певних рівнів військового управління (тактичного, оперативно-тактичного та оперативно-стратегічного) в системі військової освіти здійснювалася за схемою, що представлено на рисунку 1 [14].

Організація підготовки офіцерів здійснювалася згідно 3 наказом Міністерства оборони України (МОУ) та Міністерства освіти і науки України (МОНУ) № 221/217 від 13.04.05 «Про затвердження Інструкції про організацію освітньої діяльності у вищих військових навчальних закладах Збройних Сил України та військових навчальних підрозділах вищих навчальних закладів України» за певними освітньо-кваліфікаційними рівнями та спеціальностями (спеціалізаціями), що були затверджені наказом Міністерства оборони України № 408 від 19.06.2012 «Про затвердження Переліків спеціальностей та спеціалізацій, за якими здійснюється підготовка військових фахівців у вищих військових навчальних закладах та військових навчальних підрозділах вищих навчальних закладів за відповідними освітньо-кваліфікаційними рівнями». 


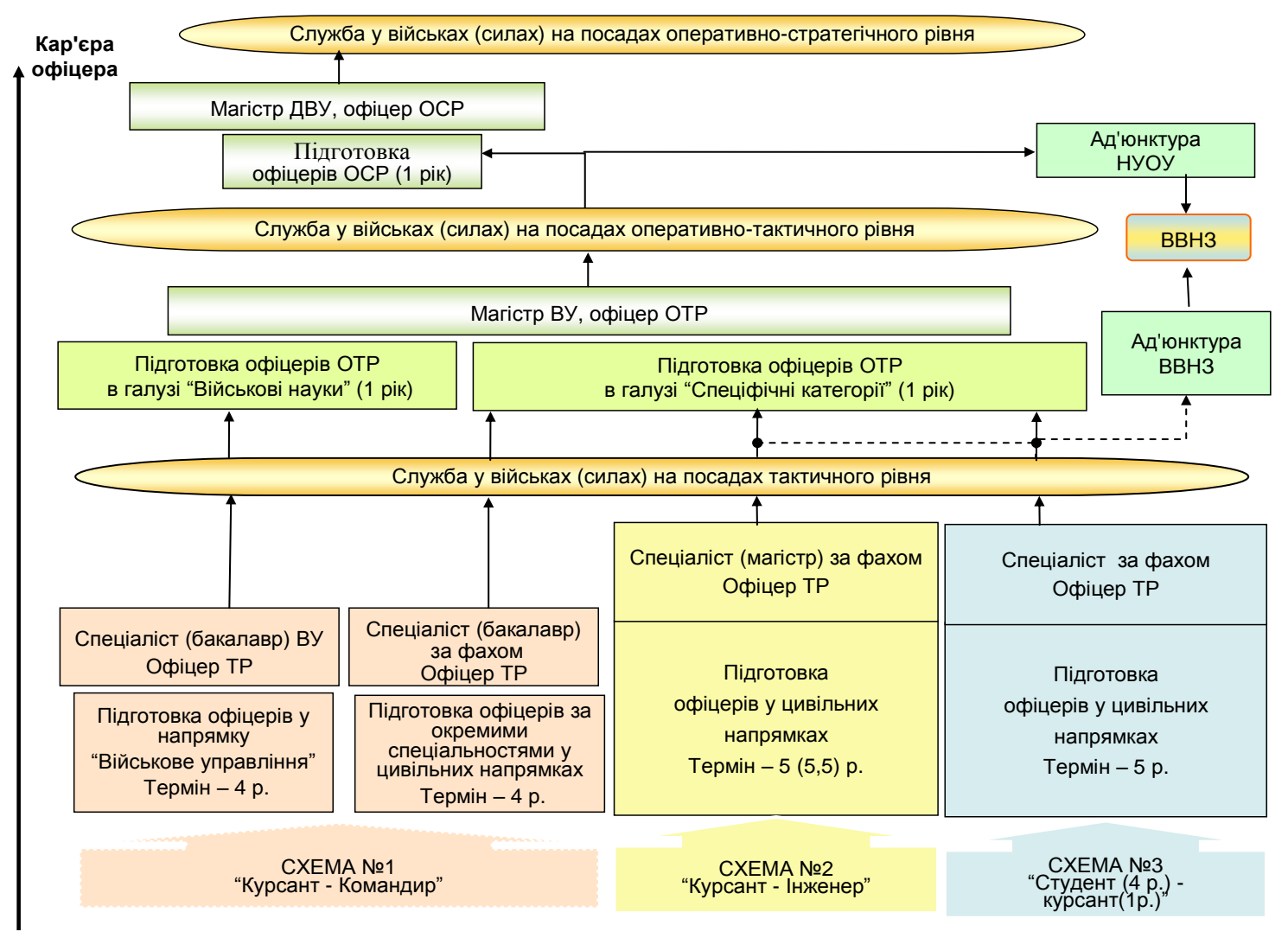

Рис. 1 - Схема підготовки офіцерів в системі військової освіти до 2014 року

Підготовка офіцерів тактичного рівня здійснювалась за 38-ю напрямами, 53-ма спеціальностями та 97-ю спеціалізаціями, офіцерів оперативнотактичного рівня за 4-ма напрямами, 15-ю спеціальностями та 38-ю спеціалізаціями, офіцерів оперативно-стратегічного рівня за 1-м напрямом, 1ю спеціальністю та 18-ю спеціалізаціями,

В основу формування Переліку спеціальностей (спеціалізацій), за якими у вищих військових навчальних закладах (BВН3) здійснювалася підготовка військових фахівців з вищою освітою, було покладено структуру майбутньої професійної діяльності офіцера за об'єктно-діяльнісною та функціональнопредметною ознаками. Це дало змогу значно скоротити номенклатуру спеціальностей (спеціалізацій) підготовки офіцерів шляхом об'єднання споріднених, виключити дублювання підготовки військових фахівців 3 малочисельних спеціальностей у різних ВВНЗ. Враховуючи специфіку підготовки військових фахівців, зазначений Перелік спеціальностей був складовою частиною державного переліку. Спеціальності та спеціалізації цього Переліку відносилися до галузі знань «Військові науки» та їх умовно можливо поділити на три групи.

До першої групи входили спеціальності підготовки офіцерів командного профілю тактичного рівня, які базувалися на напряму підготовки «Військове управління». До другої групи, як правило, відносилися спеціальності підготовки офіцерів інженерного та гуманітарного профілів тактичного рівня, які базувалися на інших (цивільних) напрямах підготовки. До третьої групи 
відносилися спеціальності підготовки офіцерів, за якими проводилася підготовка офіцерів оперативно-тактичної та оперативно-стратегічної ланок.

За спеціальностями галузі знань «Військові науки» мала місце підготовка біля 70 відсотків офіцерських кадрів. Решта офіцерів готувалася за спеціальностями, що споріднені з цивільними і мали військові спеціалізації. Це були, як правило, малочисельні спеціальності, підготовка за якими проводилася у військових інститутах (факультетах, кафедрах) цивільних вищих навчальних закладів.

Військова освіта $є$ складової частиною загальнодержавної системи освіти, тому підготовка військових фахівців організовувалася на основі державної законодавчої та нормативно-правової бази 3 урахуванням військовопрофесійних особливостей у підготовці фахівців різних силових міністерств (відомств).

Основні державні вимоги до освітньо-кваліфікаційних рівнів підготовки фахівців в Україні на тої час визначало Положення про ступеневу освіту, яке було схвалене Кабінетом Міністрів України та затверджене наказом Міністерства освіти України № 3 від 9 січня 1997 року. У Положенні, зокрема, була визначена суть освітньо-кваліфікаційних рівнів та нормативні терміни навчання : бакалавр - до 4 років, спеціаліст - до 1 року, магістр (на базі відповідної освітньо-професійної програми підготовки спеціаліста - до 1 року). При цьому, характерною ознакою підготовки фахівця було встановлення можливості здобуття вищої освіти у певної галузі знань ступенево (за виключенням спеціальностей, які відносилися до галузі «Специфічні категорії».

Тому передбачалися такі схеми навчання.

Схема № 1. Підготовка офіцерів тактичного рівня командного фаху здійснювалася, в основному, у професійному напряму «Військове управління», а також в інших цивільних напрямах. Термін навчання -4 роки. Протягом всього терміну навчання ті, хто навчалися, мали статус курсанта. При цьому, після закінчення навчання на 3-му курсі ВВНЗ курсанти отримували освітньокваліфікаційний рівень бакалавра та продовжували навчання ще 1 рік. Випускники здобували освітньо-кваліфікаційний рівень спеціаліста військового управління або спеціаліста за певним фахом.

Схема № 2. Підготовка офіцерів тактичного рівня інженерного фаху здійснювалася, як правило, у цивільних професійних напрямах. Термін навчання - $5(5,5)$ роки. Протягом всього терміну навчання ті, хто навчалися, мали статус курсанта. При цьому, після закінчення навчання на 4-му курсі ВВНЗ курсанти отримували освітньо-кваліфікаційний рівень бакалавра за відповідним професійним напрямом та продовжували навчання ще $1-1,5$ рік за певною військовою спеціальністю. Випускники здобували освітньокваліфікаційний рівень спеціаліста (магістра) за певним фахом.

Схема № 3. Підготовка офіцерів тактичного рівня гуманітарного фаху здійснювалася, як правило, за цивільними професійними напрямами у військових навчальних підрозділах вищих навчальних закладів (ВНП ВНЗ). Термін навчання - 5 роки. Ti, хто навчалися, протягом 4-х років навчання мали статус студента (за цей період вони здобували освітньо-кваліфікаційний рівень 
бакалавра). Після цього вони укладали контракт на проходження військової служби на офіцерських посадах після випуску з ВНЗ, продовжували навчання ще 1 рік за певною військовою спеціалізацією. Випускники здобували освітньокваліфікаційний рівень спеціаліста за певним фахом.

Після проходження військової служби у військах (силах) та призначення на посади певного рівня офіцери мали право продовжити навчання для здобуття оперативно-тактичного рівня військової освіти у Національному університеті оборони України. Термін навчання - 2 роки. Підготовка здійснювалася у галузі знань «Військові науки» (для офіцерів командного фаху) або у галузі «Специфічні категорії» (для решти офіцерів). Випускники здобували освітньокваліфікаційний рівень магістра та кваліфікацію офіцера військового управління оперативно-тактичного рівня.

Підготовка офіцерів оперативно-стратегічного рівня здійснювалася у Національному університеті оборони України у галузі знань «Державне управління». Термін навчання - 2 роки. Випускники здобували освітньокваліфікаційний рівень магістра державного військового управління та кваліфікацію офіцера військового управління оперативно-стратегічного рівня.

Після прийняття Верховною Радою України нової редакції Закону України «Про вищу освіту» [6] підготовка офіцерів стала проводитися за схемою, яка представлена на рисунку 2 , при цьому були внесені певні інституційні зміни.

1. Підготовка офіцерів почала здійснюватися за відповідними освітніми (науковими) програмами на таких рівнях вищої освіти: першому (бакалаврському); другому (магістерському); третьому (освітньо-науковому) та науковому. Відповідно введено наступні ступені, що присуджуються випускникам ВНЗ: бакалавр (термін навчання - 180-240 кредитів ЕСКТ); магістр (термін навчання - 90-120 кредитів ЕСКТ); доктор філософії (нормативний термін становить 4 роки, при цьому обсяг освітньої складової програми підготовки становить 30-60 кредитів ЕСКТ), доктор наук.

Бакалаврський рівень вищої освіти передбачає набуття офіцерами здатності до розв'язування складних спеціалізованих задач протягом проходження військової служби. Магістерський рівень передбачає набуття здатності до розв'язування задач дослідницького та/або інноваційного характеру. Освітньонауковий рівень передбачає набуття офіцерами здатності розв'язувати комплексні проблеми в галузі професійної та/або дослідницько-інноваційної діяльності. 


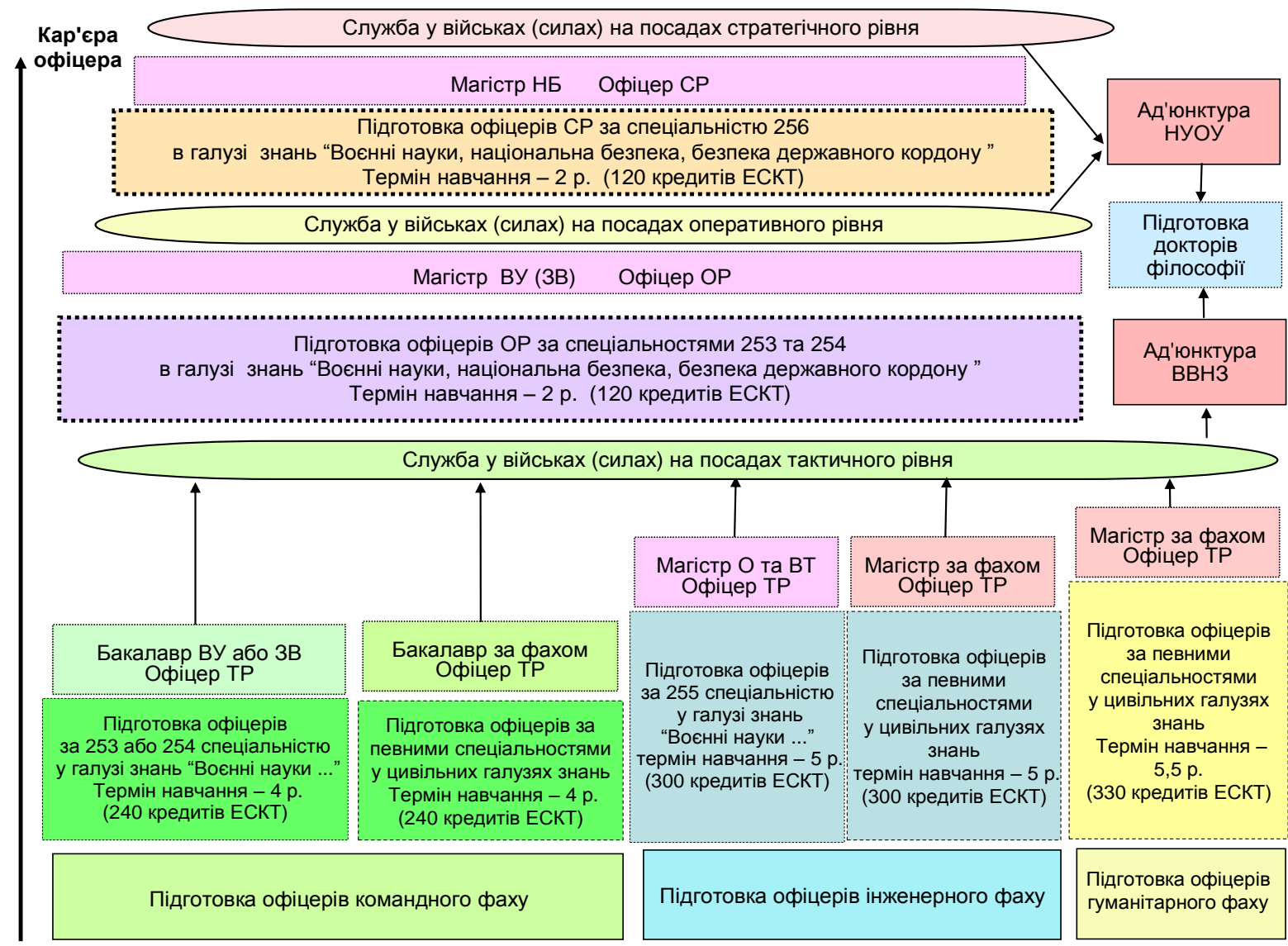

Рис. 2 - Схема підготовки офіцерів в системі військової освіти після прийняття нової редакції Закону України «Про вищу освіту»

2. Значно скоротився перелік спеціальностей підготовки офіцерських кадрів. Підготовка офіцерів тактичного рівня стала здійснюватися: у 15-и галузях знань, зокрема, у галузі знань 25 «Воєнні науки, національна безпека, безпека державного кордону» за 3-ма спеціальностями (253 «Військове управління (за видами збройних сил)», 254 «Забезпечення військ (сил)» та 255 «Озброєння та військова техніка»); 14-и цивільних галузях знань за 21-ю спеціальністю); за 83-ма спеціалізаціями (освітніми програмами). Офіцерів оперативно-тактичного рівня - у галузі знань «Воєнні науки, національна безпека, безпека державного кордону» за 2-ма спеціальностями та 38-ю спеціалізаціями, офіцерів оперативно-стратегічного рівня - у галузі знань «Воєнні науки, національна безпека, безпека державного кордону» за спеціальністю 256 «Національна безпека (за окремими сферами забезпечення i видами діяльності)» 3 спеціалізацією «Стратегічне керівництво у секторі безпеки».

3. Розроблено та затверджено відповідними наказами Міністерства освіти i науки України стандарти вищої освіти, як сукупність вимог до освітніх програм, які є спільними для всіх освітніх програм у межах певного рівня вищої освіти та спеціальності. Стандарти вищої освіти розроблено для кожного рівня вищої освіти в межах кожної спеціальності відповідно до Національної рамки кваліфікацій. Вони використовуються для визначення та оцінювання якості 
вищої освіти та результатів освітньої діяльності ВВН3, результатів навчання випускників за відповідними спеціальностями.

Стандарт вищої освіти визначає такі вимоги до освітньої програми: обсяг кредитів ЄКТС, необхідний для здобуття відповідного ступеня вищої освіти; вимоги до рівня освіти осіб, які можуть розпочати навчання за цією програмою, та результатів їх навчання; перелік обов'язкових компетентностей випускника; нормативний зміст підготовки здобувачів вищої освіти, сформульований у термінах результатів навчання; форми атестації здобувачів вищої освіти; вимоги до створення освітніх програм підготовки за галуззю знань; вимоги професійних стандартів (за їх наявності).

4. Значно зросли вимоги до якості освіти, що здобувається випускниками. Запроваджено внутрішня система забезпечення якості освіти ВВНЗ та зовнішня система забезпечення якості. Створено постійно діючий колегіальний орган Національне агентство із забезпечення якості вищої освіти (НАЗЯВО), який реалізує державну політику щодо забезпечення якості вищої освіти.

5. Ліцензування, як процедура визнання спроможності ВВНЗ проводити освітню діяльність, що спрямована на організацію, забезпечення та реалізацію освітнього процесу за певною спеціальністю підготовки офіцерів, здійснюється МОНУ, а НАЗЯВО проводить акредитацію конкретних освітніх програм навчання військових фахівців.

3 метою подальшого вдосконалення підготовки офіцерських кадрів та 3 метою наближення процесу їх навчання до основних принципів, які прийняті у країнах-членах НАТО, у систему військової освіти були впроваджені подальші інституційні зміни. При цьому, схема підготовка офіцерів зазнала також деяких змін і на цей час має вигляд, що наведено на рис. 3.

В систему підготовки офіцерського складу введено нове поняття «професійна військова освіта». До професійної військової освіти віднесено курси, що формують фахові компетенції тих, хто навчаються, на певних етапах здобуття військової освіти: L-1, L-2, L-3, L-4. Ці курси отримали назву «лідерські курси». Курс L-1, що є складовою навчального плану підготовки офіцерів тактичного рівня у ВBН3, поділяється на три частини: L-1A; L-1B; L$1 \mathrm{C}$.

3 метою використання єдиного підходу в організації освітнього процесу у ВВНЗ здійснюється розподіл фахових компетентностей на військовопрофесійні компетентності (далі - ВПК) та військово-спеціальні компетентності (далі - ВСК). ВСК відображають специфіку конкретної предметної сфери професійної діяльності (спеціалізації) військового фахівця. ВСК за спеціалізацією визначають вимоги замовника на підготовку офіцера щодо компетентностей та результатів навчання за конкретною спеціалізацією. 


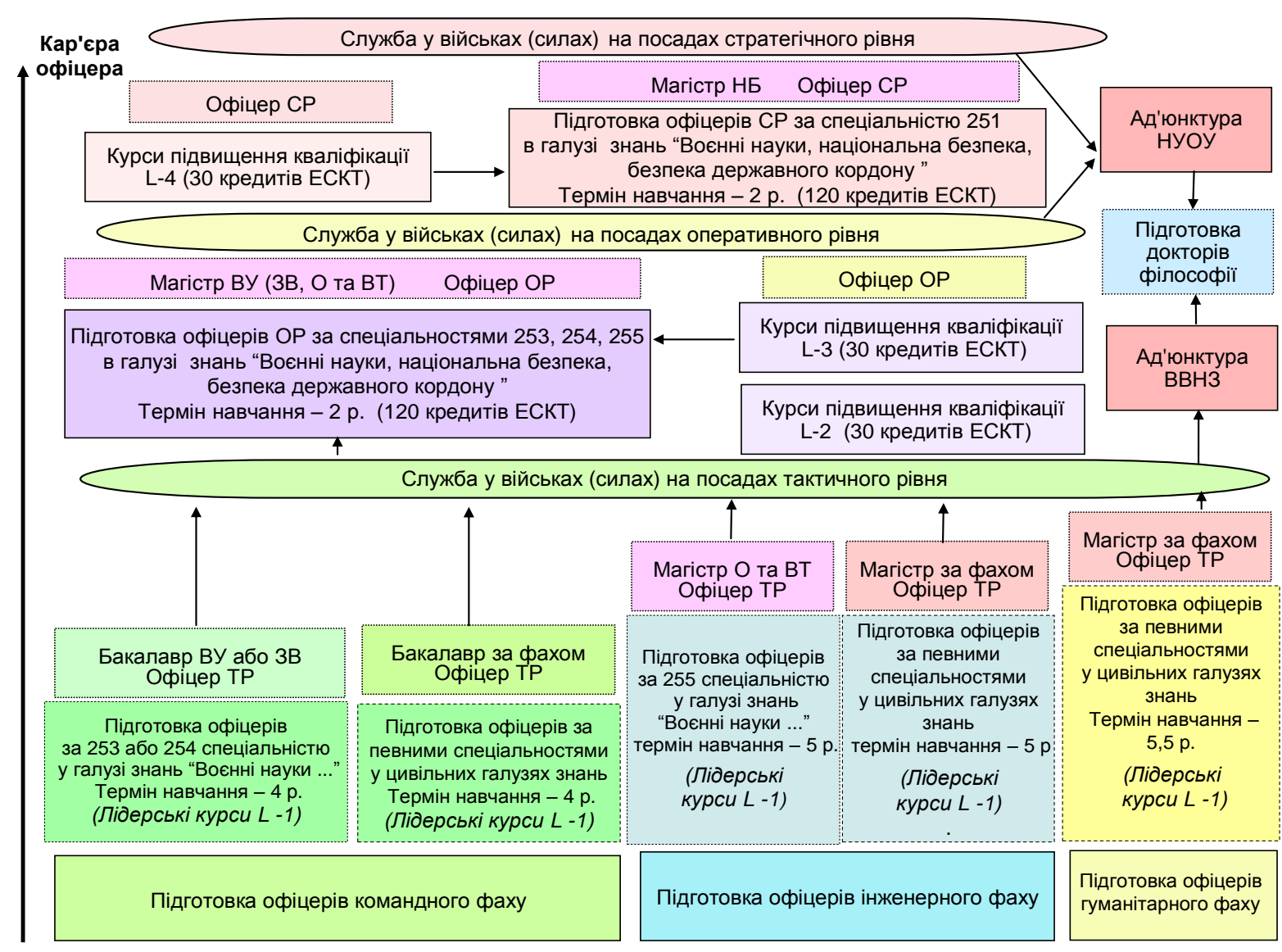

Рис. 3 - Схема підготовки офіцерів в системі військової освіти, що запроваджена, починаючи з 2019 року

ВПК офіцера тактичного рівня формуються у процесі опанування базового курсу професійної військової освіти (BASIC OFFICER LEADER COURSE) L1A, обсягом 35 кредитів ЄКТС, як військово-професійної складової освітньої програми, i який $\epsilon$ однаковим для офіцерів тактичного рівня всіх спеціальностей підготовки, та фахових курсів професійної військової освіти (SPECIALITY TRAINING COURSE) L-1B (взвод) і L-1C (рота), обсягом до 30 кредитів ЄКТС.

Оперативний та стратегічний рівні військової освіти можна здобути через систему курсів підвищення кваліфікації без підвищення рівня вищої освіти.

Метою командно-штабних курсів видів збройних сил (COMPONENT COMMAND COURSE) L-2 $є$ підготовка офіцерів для подальшого призначення на посади командирів батальйонів (дивізіонів, авіаційних ескадрилій), начальників родів військ і служб, офіцерів штабу, заступників командирів бригад (полків). Курс орієнтований на вивчення порядку роботи посадових осіб під час планування та ведення бою (бойових дій) батальйону та бригади (полку) в операціях угруповань військ. Курс має обсяг 30 кредитів СКТС.

Основним призначенням курсу офіцерів об'єднаних штабів оперативного рівня (JOINT HEADQUARTERS COURSE ) L-3 є підготовка - офіцерів для призначення на посади оперативного рівня. Вона здійснюється 3 метою формування певних компетентностей для забезпечення діяльності лідерів оперативного рівня, здатних розв'язувати складні задачі та проблеми, що 
характеризуються невизначеністю умов у галузі управління діями військових частин родів військ видів збройних сил у складі міжвидових угруповань військ (сил), планування та ведення операцій міжвидових угруповань військ органами військового управління оперативного рівня, а також їх всебічного забезпечення під час спільного виконання ними завдань в операціях (бойових діях) та максимальної реалізації оперативних (бойових) можливостей угруповань військ (сил). Курс спланований обсягом 30 кредитів СКТС.

Метою курсу вищого керівного складу стратегічного рівня (L-4) є підготовка офіцерів для просування по службі на посади стратегічного рівня. Вона здійснюється 3 метою вивчення теоретичних основ діяльності лідерів стратегічного рівня, сучасних міжнародних відносин, стратегічного управління конфліктами, оборонного менеджменту, підготовки і застосування сил оборони для стримування й відсічі збройної агресії та методологічних підходів до формування стратегій для підвищення ефективності рішень, що приймаються під час виконання службових обов'язків. Головним завданням курсу є розвиток у слухачів управлінських компетентностей, що властиві керівникам стратегічного рівня через ознайомлення з основними стратегічними теоріями та моделями стратегічного лідерства, а також поглиблення певних теоретичних знань та вдосконалення вмінь і практичних навичок.

Наприкінці проведеного аналізу зазначимо, що курси, які розглянуто вище, реалізуються у рамках неформальної вищої освіти. При певному нормативному забезпеченні результати навчання на цих курсах можна врахувати при здобуті наступних рівнів вищої освіти у рамках формальної освіти.

Висновки. Сьогодні система військової освіти перебуває на шляху подальшого реформування, що обумовлено новими ризиками і загрозами для нашої держави та, відповідно, новими, більш високими вимогами до захисників ii територіально цілісності та незалежності. Ставши на шлях інтегрування в європейську та євроатлантичну спільноту, поставлено амбітні завдання, в тому числі - підняти рівень підготовки офіцерських кадрів до європейських стандартів. Останнім часом МОУ зроблено багато послідовних кроків у цьому напрямку, інституційні зміни у системі підготовки офіцерів, що розглянуті, один із них.

\section{ЛІТЕРАТУРА}

1. Закон України «Про національну безпеку України»: № 2469-VIII від 21 червня 2018 р. [Електронний ресурс]. - Режим доступу: https://zakon.rada.gov.ua/laws/show/2469.

2. Указ Президента України № 555/2015 від 24 вересня 2015 р. «Про рішення Ради національної безпеки і оборони України від 2 вересня 2015 року «Про нову редакцію Воєнної доктрини України»: [Електронний ресурс]. - Режим доступу: https://zakon.rada.gov.ua/laws/show/555/2015.

3. Указ Президента України № 92/2016 від 14.03.2016. «Про Концепцію розвитку сектору безпеки i оборони України»: [Електронний ресурс]. - Режим доступу: http://zakon.rada.gov.ua/laws/show/92/2016.

4. Указ Президента України № 240/2016 від 6 червня 2016 р. «Про рішення Ради національної безпеки і оборони України від 20 травня 2016 року «Про Стратегічний оборонний бюлетень України»: [Електронний ресурс]. - Режим доступу: https://zakon.rada.gov.ua/laws/show/240/2016\#n251. 
5. Указ Президента України № 73/2017 від 22 березня 2017 р. «Про рішення Ради національної безпеки і оборони України» від 29 грудня 2016 року «Про Державну програму розвитку Збройних Сил України на період до 2020 року»: [Електронний ресурс]. - Режим доступу: https://zakon.rada.gov.ua/laws/ show/73/2017\#n2.

6. Закон України» № 1556-VII від 1 липня 2014 р. «Про вищу освіту». [Електронний pecypc]. - Режим доступу : https://zakon.rada.gov.ua/laws/show/1556-18.

7. Нещадим М. І. Військова освіта в Україні: історія, теорія, методологія, практика: [монографія] / М. І. Нещадим - К. : Київський університет, 2003. - 852 с.

8. Нещадим М. І. Військова освіта як цілісна система /М. І. Нещадим, Ю. І. Приходько // Військова освіта. - 2003. - № 11. - С. 3-17.

9. Приходько Ю. І. Основи теорії трансформації систем /Ю.І.Приходько / Вісник Київського національного університету ім. Т. Шевченка. Серія «Філософія». - 2018. № 1 (3). - С. 21-27.

10. Приходько Ю. І. Актуальні проблеми сучасного етапу роз витку військової освіти /Ю. І. Приходько //Освіта дорослих: теорія, досвід, перспективи. - 2017. - № 1 (13). - С. 275282.

11. Дуглас Норт. Институты, институциональные изменения и функционирование экономики [Електронний ресурс].- Режим доступу: http://cee-moscow.com/doc/izd/North.pdf.

12. Мочерний С. В. Економічний енциклопедичний словник: /C. В. Мочерний, Я. С Ларіна, О. А. Устинко, С. І. Юрій /За ред. С. В. Мочерного. - Львів: Світ, 2005, 283с.

13. Шапкин В. В. Институализм как методология исследования образования: моногр. /В. В Шапкин., А. В. Василенко // Изд-во РГППУ им. А. И. Герцена, 2005, 72 с.

14. Про створення єдиної системи військової освіти: Постанова Кабінету Міністрів України № 1410 від 15 грудня 1997 р. [Електронний ресурс]. - Режим доступу : https://zakon.rada. gov.ua/laws/show/1410-97-п.

\section{REFERENCES}

1. Zakon Ukrayiny (2018), № 2469-VIII «Pro natsionalnu bezpeku Ukrayiny», [Law of Ukraine «On national security of Ukraine»], available at: https://zakon.rada.gov.ua/laws/-show/2469, (in Ukrainian).

2. Ukaz Prezydenta Ukrayiny (2015), № 555/2015 «Pro rishennya Rady natsionalnoyi bezpeky i oborony Ukrayiny vid 2 veresnya 2015 roku «Pro novu redaktsiyu Voyennoyi doktryny [Decree of the President of Ukraine № 555/2015 «On the decision of the National Security and Defense Council of Ukraine of September 2, 2015 «On the new version of the Military Doctrine of Ukraine »]. Available at: https://zakon.rada.-gov.ua/laws/show/555/2015.

3. Ukaz Prezydenta Ukrayiny (2016), № 92/2016 «Pro Kontseptsiyu rozvytku sektoru bezpeky i oborony Ukrayiny», [Decree of the President of Ukraine «On the Concept of Development of the Security and Defense Sector of Ukraine»], available at: http://zakon.rada.gov.ua/laws/show/92/2016, (in Ukrainian).

4. Ukaz Prezydenta Ukrayiny (2016), № 240/2016 «Pro rishennya Rady natsionalnoyi bezpeky i oborony Ukrayiny vid 20 travnya 2016 roku «Pro Stratehichnyy oboronnyy byuleten Ukrayiny», [Decree of the President of Ukraine «On the decision of the National Security and Defense Council of Ukraine of May 20, 2016 «On the Strategic Defense Bulletin of Ukraine »], available at: https://zakon.rada.gov.ua/laws/show/240/2016\#n251, (in Ukrainian).

5. Ukaz Prezydenta Ukrayiny (2017), № 73/2017 «Pro rishennya Rady natsionalnoyi bezpeky i oborony Ukrayiny vid 29 hrudnya 2016 roku «Pro Derzhavnu prohramu rozvytku Zbroynykh Syl Ukrayiny na period do 2020 roku»»), [Decree of the President of Ukraine «On the decision of the National Security and Defense Council of Ukraine of December 29, 2016 «On the State Program for the Development of the Armed Forces of Ukraine until 2020»], available at: https://zakon.rada.gov.ua/laws/ show/73/2017\#n2, (in Ukrainian).

6. Zakon Ukrayiny (2014), № 1556-VII «Pro vyshchu osvitu», [Law of Ukraine «About higher education»], available at: https://zakon.rada.gov.ua/laws/show/1556-18, (in Ukrainian). . 
7. Neshchadym M. I. (2003), Viiskova osvita v Ukrainy: istoriia, teoriia, metodolohiia, praktyka [Military education of Ukraine: history, theory, methodology, practice]. Kyiv. Vydavnychopolihrafichnyi tsentr "Kyivskyi universytet", 852 p, (in Ukrainian).

8. Neshchadym M. I., Prykhodko Yu. I (2003), Viyskova osvita yak tsilisna systema [Military education of Ukraine: history, theory, methodology, practice], Military education, 11, 3-17, (in Ukrainian).

9. Prykhodko Yu. I. (2018), Osnovy teoriyi transformatsiyi system [Fundamentals of systems transformation theory], Bulletin of Kyiv National University. Philosophy series, 1 (3), 21-27, (in Ukrainian).

10. Prykhodko Yu. I. (2017), Aktualni problemy suchasnoho etapu rozvytku viyskovoyi osvity [Actual problems of the modern stage of development of military education], Adult education: theory, experience, prospects, 1 (13), 275-282, (in Ukrainian).

11. Duglas Nort. (1998), Instituty, institutsional'nyye izmeneniya i funktsionirovaniye ekonomiki [Institutions, institutional change and economic performance], available at: http://ceemoscow.-com/doc/izd/North.pdf, (in Russian).

12. Mochernyy S. V., Larina Ya. S., Ustynko O. A., Yuriy S. I. (2005), Ekonomichnyy entsyklopedychnyy slovnyk [Economic encyclopedic dictionary], Lviv: Svit, 283, (in Ukrainian).

13. Shapkin V. V.,. Vasilenko A. V (2005), Institualizm kak metodologiya issledovaniya obrazovaniya [Institutionalism as a methodology for the study of education], Publishing house of RGPPU name after. A. I. Herzen, 72, (in Russian).

14. Pro stvorennya yedynoyi systemy viyskovoyi osvity: Postanova Kabinetu Ministriv Ukrayiny, № 1410 (1997), [On the creation of a unified system of military education: Resolution of the Cabinet of Ministers of Ukraine, № 1410 of December 15, 1997], available at: https://zakon.rada. gov.ua/laws/show/1410-97-п. (in Ukrainian).

\section{РЕЗЮМЕ}

Ольга Черных,

Национальный университет обороны Украины имени Ивана Черняховского

Юрий Черных, кандидат технических наук, доцент Военный институт Киевского национального университета имени Тараса Шевченко

\section{Анализ институциональных изменений в системе подготовки офицерских кадров}

В статье обоснована актуальность исследования институциональных изменений в системе подготовки военных специиалистов с высшим образованием. Необходимость конструктивных изменений в системе подготовки офищерских кадров, приведение организачии и содержания их обучения к современным условиям требует расширения категориального аппарата исследования этих явлений на основе применения методологического инструментария современного институционализма. С учетом теоретических положений институционализма проанализированы основные изменения, произочедшие в последние годы в системе подготовки офицерских кадров тактического, оперативного и стратегического уровней военного управления.

Ключевые слова: система подготовки; офицерские кадры; институциональные изменения; лидерские курсы. 
SUMMARY

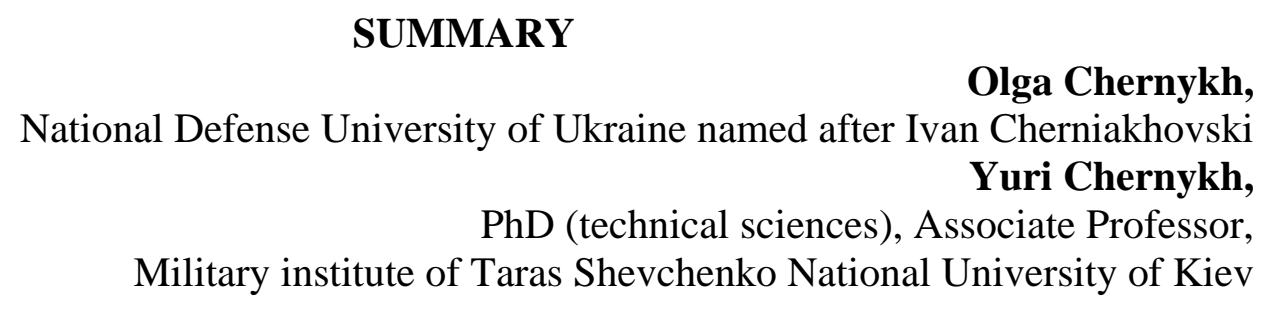

\section{Analysis of institutional changes in the officer training system}

Introduction. The article substantiates the relevance of the study of institutional changes in the system of training military specialists with higher education. The need for constructive changes in the system of officer training requires the expansion of the categorical apparatus of research of these phenomena on the basis of the application of methodological tools of modern institutionalism. At the same time, the analysis of institutional changes that have taken place in recent years in the system of officer training requires a systematic approach. It is proved that the analysis of the transformation of institutions involves the study of the phenomenon of dependence on their previous development. Taking into account the theoretical provisions of institutionalism, the main changes that have taken place in recent years in the system of officer training are analyzed. Keywords: training system; officers; institutional changes; leadership courses.

Purpose. Analyze the institutional changes that have taken place in recent years in the system of officer training, and take into account the experience of reforming the national system of military education to improve the training of military professionals.

Methods. The study was conducted using the following theoretical methods: analysis and synthesis, induction and deduction, comparison, classification, generalization and systematization.

Results. Taking into account the theoretical provisions of modern institutionalism, the main changes that have taken place in recent years in the system of officer training in the Armed Forces of Ukraine are considered.

Originality. According to the purpose of the paper, analyze the institutional changes that have taken place in recent years in the system of officer training, and take into account the experience of reforming the national system of military education to improve the training of military professionals.

Conclusion. The system of military education in Ukraine is on the path of further reform, due to new risks and threats to our state. This places new high demands on the defenders of its territorial integrity and independence. Having embarked on the path of integration into the European and Euro-Atlantic community, we have set ambitious goals. One of the tasks is to raise the level of training of officers to European standards. Ministry of Defense of Ukraine has taken many successive steps in this direction. The institutional changes in the officer training system under consideration are one of them.

Key words: training system; officers; institutional changes; leadership courses. 